\title{
Antisemitism and Protestant Churches: A Quest for Reform
}

\section{A Troubling Question}

The International Holocaust Remembrance Alliance (IHRA) published this working definition for antisemitism in 2016:

Antisemitism is a certain perception of Jews, which may be expressed as hatred toward Jews. Rhetorical and physical manifestations of antisemitism are directed toward Jewish or non-Jewish individuals and/or their property, toward Jewish community institutions and religious facilities.

The first by-line of the definition clarifies that "manifestations might include the targeting of the state of Israel, conceived as a Jewish collectivity."

By now it is a common place that modern antisemitism includes, if not targets, the State of Israel. Antisemitism presents itself as a global movement with international support for the boycott of the Jewish State. The BDS movement (Boycott, Divestment, Sanctions) is one of the center pieces in the attempt of delegitimizing the Jewish State. Having been initiated in Iran in 2000, BDS went global with the United Nations' World Conference against Racism 2001 in Durban, South Africa. Since then, BDS receives its finance and workforce through secular NGOs and its cultural acceptance through religious church institutions. Churches provide BDS educational tools. Those instructions include the antisemitic Kairos-Palestine Document, the Israel-maligning volunteer programs like EAPPI (Ecumenical Accompaniment Program in Palestine and Israel) with its various off-shoots, and the antisemitic Palestinian Liberation "Theologies" produced by, for example, Naim Ateek and Mitri Raheb. Those socio-religious projects are sponsored by the World Council of Churches and financed by a number of its affiliated Protestant church leadership in-groups. ${ }^{2}$

1 International Holocaust Remembrance Alliance, "Working Definition of Antisemitism," issued May 26, 2016, https://www.holocaustremembrance.com/news-archive/working-definition-anti semitism.

2 For references, see the research database of NGO-Monitor, https://www.ngo-monitor.org/ ngos/.

Ә OpenAccess. () 2020 Petra Heldt, published by De Gruyter. (cc) BY-NC-ND This work is licensed under the Creative Commons Attribution-NonCommercial-NoDerivatives 4.0 License. 
The term "Protestant church leadership in-groups" distinguishes that faction in the Protestant churches from regular Protestant church leaders and their flocks who are often innocent of the in-group's activities. Current research ${ }^{3}$ shows that Protestant church service forces, elected or tenured, who are involved in those activities, veil their antisemitic intentions and mislead the church and the public at large. Those church officials put a veneer of morality on the steady stream of disinformation about the State of Israel and the Palestinian areas. While often referring to church documents that show respect for Jews and Judaism, those church in-groups can, simultaneously, show actions and publications that malign Israel's vigilance against terrorism ${ }^{4}$ and undermine her efforts in building a democratic state in the face of war and terrorism. The discourse of such officials appears to be manipulative because known information is often hidden from the public. The aim seems to be the calculated control over public opinion regarding Israel.

Currently, Christian and Jewish scholars and clergy are frequently sidelined and delegitimized ${ }^{5}$ when wanting to publish and speak about the complex reality of the Jewish State in Protestant churches. The exclusion of alternative information is an attempt by some in-groups to protect their false narrative of an invented history of Israel. The church publications of EAPPI, the Kairos-Palestine Document, and Raheb's Palestine narrative are cases in point. ${ }^{6}$ Each one of them

3 Cf. P. Heldt, “Christen im Nahen Osten: Orientierungspunkt Israel,” Kirche und Israel: Neukirchener Theologische Zeitschrift 32, no. 2 (2017): 153-65; P. Heldt, "Mitri Raheb: Glaube unter imperialer Macht. Eine palästinensische Theologie der Hoffnung," Kirche und Israel: Neukirchener Theologische Zeitschrift 31, no. 2 (2016): 134-48; articles by M. Lowe at Gatestone Institute, see https://de.gatestoneinstitute.org/author/Malcolm+Lowe and the articles by D. van Zile in CAMERA, see https://www.camera.org/camera-author/dexter-van-zile/.

4 Cf. my presentation at the NGO-Monitor Conference on EAPPI in Jerusalem in 2016, and Malcolm Lowe's exposé at that conference on the WCC, cf. P. Heldt, "World Council of Churches Favors Nationalism and Anti-Semitism: The Kairos Palestine Document and Alternative Tourism," Gatestone Institute, issued January 22, 2017, https://www.gatestoneinstitute.org/9800/wcckairos-antisemitism; M. Lowe, "World Council of Churches Struggles with the Truth-Again," Gatestone Institute, issued March 6, 2016, https://www.gatestoneinstitute.org/7565/world-coun cil-of-churches-water.

5 A case in point is NGO-Monitor and its scholars. I was told that analytical evidence published by NGO-Monitor is unacceptable in scholarly discourse since it is, as it were, biased in favor of the State of Israel and thus untrustworthy. Cf. also a case regarding Facebook which points to similar techniques, presented by Phyllis Chesler, "How I Was Rejected by Facebook-and Won,” Arutz Sheva, September 13, 2018, https://www.israelnationalnews.com/Articles/Article. aspx/22729.

6 Cf. the numerous Gatestone articles on those subjects, especially those authored by Malcolm Lowe, https://de.gatestoneinstitute.org/author/Malcolm+Lowe. Also cf. my article "Fortpflan- 
guards over the false claim that the Palestinian people were an ancient people that lived since time immemorial in a land called Palestine. Widely distributed by some Protestant church officials in Europe and the US ${ }^{7}$, none of those imaginary stories refer to the documented history that, for example, the Roman Empire punished the people of Israel for defending its land, Eretz Israel, in the Bar Kokhba uprising in 135 C.E. by replacing the name of Israel with that of Palestine. The re-naming had no lasting effect until three twentieth-century attempts applied the Roman-invented name to the land. Some Lutheran antisemitic replacement theologians called Israel "Palestine"; the British Mandate renamed Eretz Israel as "Palestine"; the Muslim leader Yasser Arafat propagated a Muslim state of Palestine in the Land of Israel. BDS activists feed on a history of the land as "Palestine" that starts with the PLO leader Arafat in 1968.

The in-groups' manipulative discourse thrives on purposefully selected memory on the one hand, and on narratives that contest, marginalize, and suppress alternative views by ignoring, labeling, and smearing opposing voices on the other. The result makes the church look like it is developing Protestant church-sponsored antisemitic hegemony over Israel. The method of the manipulative discourse is social bullying. That unethical misconduct in the church makes a church appear like a pseudo Christian sect, that intends to change the social fabric of a society at large and is set to cause harm to Israel.

\section{Research Context}

The perception of manipulation of discourse by Protestant church in-groups with the aim of nurturing and sustaining antisemitism in the public sphere is best placed within two interconnected research areas, (1) Critical Discourse Analysis (CDA) and (2) biblical hermeneutics.

\section{(1) Critical Discourse Analysis (CDA)}

Teun van Dijk, ${ }^{8}$ an acclaimed CDA scholar at the University of Barcelona, shows that the manipulation of discourse ${ }^{9}$ is a social aberration based on a three-angu-

zung einer Mentalität,” Kirche und Israel: Neukirchener Theologische Zeitschrift 33, no. 1 (2018): $5-15$.

7 In addition, cf. material distributed by the Lutheran World Federation in Jerusalem, such as flags, posters, and pamphlets that show Palestine in all of the State of Israel.

8 Cf. T. A. van Dijk, "Discourse and Manipulation," Discourse \& Society 17, no. 3 (2006): 359-83. 
lar approach: (a) "a form of social power abuse"; (b) "a form of cognitive mind control"; (c) "a form of discursive interaction." within Protestant church in-group leadership that promotes antisemitism.

(a) Van Dijk's research shows that, as a social phenomenon, manipulation of discourse works through "social power abuse." Unlike democratic state institutions, Protestant churches lack independent checks and balances of appointed or tenured office holders. Checks and balances identify and eradicate manipulation of discourse. ${ }^{11}$ Lacking mechanisms to correct irregularities, such as antisemitism, church adherents have two choices: either, implicitly, to stay away from the church, or, explicitly, to resign from it. At the time of Nazi Germany when the majority of German Protestant clergy followed, nurtured, and sustained antisemitism in church and state, dismayed church members stayed away from church. Today, church members often explicitly resign from the church when they realize their impotence in fighting church-affiliated antisemitism.

Recently, Malcolm Lowe ${ }^{12}$ investigated the current decline of membership numbers in Protestant churches and suggested that the current huge wave of Protestant church-leavers is more prominent in those Protestant churches that present antisemitic hegemony over the State of Israel. Lowe's assumption is that lying about Israel in a church is a symptom for other wrong-doings of that institution. Where a Protestant church presents Israel falsely as an apartheid state with illegitimate domination and social inequity, as if being a pariah state killing Arab children or poisoning Arab wells, it might have few moral stops in lying about other things in other areas, such as sexual or financial abuse, too.

(b) As a "cognitive phenomenon," according to van Dijk, the manipulative discourse of certain Protestant church circles interferes with the process of understanding Israel in its historic and present-day reality. For the antisemitic purpose of such Protestant church in-groups that means that they manipulate the minds of congregations, pilgrims, and students with biased models and social representations, that is, as if Israel steals the land and the history of a Palestinian people. This form of manipulative discourse in the church is interlinked with the study of biblical hermeneutics which will be discussed further on.

\footnotetext{
9 As the boundaries between illegitimate manipulation and legitimate persuasion can become blurred, van Dijk assumes that "the crucial criteria are that people are being acted upon against their fully conscious will and interests, and that manipulation is in the best interests of the manipulator," van Dijk, "Discourse and Manipulation," 361.

10 van Dijk, "Discourse and Manipulation," 359.

11 See the US debate about possible manipulations of the public by a so-called "deep-state." 12 Cf. M. Lowe, "Anti-israélisme, symptôme de crise des institutions," Le Christianisme au XXe Siecle 10 (1994): $60-62$.
} 
(c) As a "discursive interaction," as per van Dijk, manipulation is exercised through texts, talks, and visual messages. Antisemitic church in-groups employ texts that describe Israel in negative language, as, for instance, in the widely distributed and church-promoted antisemitic literature of Palestinian liberation "theology." That ideology falsifies the history of the State of Israel and caricatures the democratic Jewish State as an apartheid state.

Talks also reiterate the negative image of Israel. For example, mass fora, like regional, national or international church gatherings, are employed by such ingroups for re-stating the false image of Israel. To this end, the same known antisemitic speakers tend to be invited to deliver that massage, year after year.

The visual message is yet another tool for the manipulation of discourse. Examples are the controlled pilgrimages to "Palestine"13 or films that purport antisemitic narratives, such as "The Occupation of the American Mind." The film, shown in November 2017, at the Unitarian Universalist Church in Marblehead, Massachusetts, USA, posits that Israel has "infiltrated" American media to the extent that all US media coverage on the Israeli-Palestinian conflict is biased and anti-Palestinian. ${ }^{14}$

Summing up CDA research input for the problem at hand, discursive interaction emphasizes forms and formats like our good things versus their bad things. Such manipulation by church in-groups entrenches the label on the State of Israel as, for instance, being an alleged human rights abuser while presenting an image of certain Protestant churches and WCC-controlled pilgrims as the justice-and-peace-good-doers who uphold human rights.

Van Dijk's analytical tool shows the (re)production of power abuse in the church by some in-groups through manipulative discourse which, consequently, paints Israel and its proponents as being socially unequal by the standards of the church.

However, there is a twofold question. Why do numerous other church servants and church members abstain from such antisemitic discourse? And why do they do not enough to stop the disturbing in-groups? The answer to the latter refers to the hierarchical structure of the Protestant churches. As in most churches, the superior directs the affairs. Among the clergy, contradiction gets reprimand, like-mindedness and yes-saying get promotion. While the laity has

13 Cf. the brochure issued by Brot für die Welt - Evangelischer Entwicklungsdienst, Kommt und seht! Reisen und Pilgern im Heiligen Land, issued May 2016. https://shop.brot-fuer-die-welt.de/ images/2016-06-28_pilgern_2016.pdf.

14 Cf. D. Berrini Leblang, “Area Jews Ask: Why Would a Church Show an anti-Semitic Movie?” Jewish Journal, November 2, 2017, https://jewishjournal.org/2017/11/02/area-jews-ask-why-woulda-church-show-an-anti-semitic-movie/. 
some few democratic tools, such as the community councils, it faces the fact that its rights have often been manipulated and abused in favor of the in-groups' positions. Currently, Israel-friendly Protestant church voices are frequently sidelined or even maligned. Yet such voices exist numerously. For instance, they are leading abundant Protestant church pilgrim tours with the precise aim to visit Israel and to learn about the reality of the State of Israel. There are Israel-minded church leaders, even if removed from the church center, who show overtly, in word and deed, that their Christian faith is informed by a positive and central image of Israel. They remain unimpressed by antisemitic manipulations of their colleagues. What does make the one tick and the other not?

\section{(2) Biblical Hermeneutics}

While human decency is a strong antidote to any form of antisemitism, there is also the study of biblical hermeneutics that makes or fails resistance of churchconnected antisemitic manipulation. The key concept of hermeneutics is the art of understanding. Hermeneutics and discourse studies are methodically interlinked. While discourse studies involve the strategic processing of texts and the constructing of mental models, hermeneutics show the contexts that influence the text. ${ }^{15}$

Hermeneutics in contemporary Protestant churches follow the rival conception of Israel as a real historic place and as an abstract spiritual ideal in the mind. Two opposing contexts influence the understanding of Israel in the biblical text.

Hermeneutics that read the biblical account from the perspective of historic realism understand a reference to Israel to mean Israel. In such reading, Israel is a land given to the people of Israel after their return from Egypt under Moses, marking the beginning of the history of Eretz Israel. Also, the seven divine covenants with Israel since Abraham, never revoked, have here a ring of historic realism. They are covenants, namely moral commitments, not contracts pursuing self-interests and profits.

In contrast, hermeneutics that read the biblical account as an abstract spiritual ideal in the mind will treat Israel, or any other biblical notion, such as the covenants, as a metaphor that can be replaced. If abstract, then any secular postmodern subject like racial equality, Palestine, or any other item in liberal Prot-

15 Cf. T. A. van Dijk, “Discourse Studies and Hermeneutics,” Discourse Studies 13, no. 5 (2011): 609-21. 
estantism can take obsession and become the focus of the attention and activity. If the biblical account is read in a spiritual way, replacement becomes the key. Furthermore, if free from the historic real context of the faith all the subjects are worthy in themselves. Yet the question is, whether the faith continues to be gripping; or if it is not more than any of the various secular ideas in a religious terminology.

For the impact of reading the Bible in the context of historic realism the current US-American Israel policy is of interest. Vice President Mike Pence, as reported, ${ }^{16}$ appreciates a sentence from the book of Jeremiah 29:11: "For I know the thoughts that I think toward you, said the Lord, thoughts of peace, and not of evil, to give you hope in your latter end." With historic realism, the Protestant Christian Pence reads the "you" as referring to Israel. In the abstract reading, the "you" is to be replaced by something else, such as "me," or "Palestine." In the historic reading, divinely inspired compassion for Israel is in place. In the abstract reading, divine peace and hope has nothing to do with Israel but with the subject of the liberal reader's passion.

Commonly, post-modern Bible preachers substitute the reality of the Bible with the image of their minds. Thus the reaction to Pence's Bible reading by former Lutheran Palestinian Bishop Munib Younan comes to no surprise when claiming that he is not afraid of Islamists but of the Americans. ${ }^{17}$ A pastor of the Disciples of Christ church, Rebecca Littlejohn, stated: "I find very little [...] in Mike Pence's religion that looks like Christianity to me."18 Division, indeed, and exclusion follow when abstract readings of the Bible meet historic realism.

In fact, such division in Protestant churches existed since John Calvin and Martin Luther. Calvin in Switzerland promoted biblical hermeneutics of historic realism while Luther in central Germany preferred the spiritual reading. For John Calvin and his followers, the primary reading text was the Hebrew Bible with esteem for the divine covenants with Israel. Such reading informed Calvinists in their building of political and social structures. Thus they employed the biblical concept of covenant for international affairs but the contract for business. Covenantal theology enlightened the politics of Switzerland, the Netherlands, Scot-

16 Cf. C. Ong, "U.S. Vice President Mike Pence Reveals the Bible Verse that Hangs above his Mantle,” Christian Today, February 4, 2017, https://www.christiantoday.com/article/vice-presi dent-mike-pence-reveals-the-bible-verse-thats-hangs-above-his-mantle/104411.htm.

17 Cf. D. van Zile, “CNN Errs in Relying On Anti-Israel Collaborator For Commentary About Israel,” Camera, January 17, 2018, https://www.camera.org/article/cnn-errs-in-relying-on-anti-is rael-collaborator-for-commentary-about-israel/.

18 “Palestinian Christians Slam Pence’s pro-Israel Faith.” Ynet News, January 22, 2018, https:// www.ynetnews.com/articles/0,7340,L-5074816,00.html. 
land, Cromwell's England, and the Pilgrim Fathers in North America. Precisely those countries developed any number of expressions for ahavat Zion (love of Zion). The Balfour Declaration of 1917 in the United Kingdom derives from such a context. Pence follows that path of old.

Luther and his followers, in contrast, found the key biblical texts in the epistles of Paul, reading them with a spiritual emphasis. In that reading strategy, the biblical covenants became nebulous notions and Israel was replaced by the church. Following the period of the Reformation, the Enlightenment transformed the replacement reading of the Bible even further. Now, Israel was not any longer replaced by the church alone but by any abstract idea of the mind. Israel could now be replaced by whichever subject captured the mind of Lutheran leadership in-groups. Nazism is one of the more prominent replacements. In Luther-inspired countries, their connection to the State of Israel and the Jews remained vague. In the case of Younan and Littlejohn, the replacement of Israel with Palestinians and the identification of evil with America follows the old Lutheran spiritual currency.

Unlike Protestant churches, most other churches in Israel show a synthesis between the historic realism of the Bible in the place of Israel in which they live and the spiritual worship in liturgy by which they express their hopes of the faith, often in abstract and spiritual terms. The latest expression of such synthesis can be found in the establishment of Christian Empowerment Groups in Israel (CEG). CEG enable young Christians, men and women alike, who wish to join the Israel Defense Forces to do so. CEG are organized by orthodox Christians in the North of Israel. CEG express a Christian faith that is grounded in biblical realism. This includes the understanding that Christians have no other safe home in the Middle East but Israel and that that home needs to be protected. In the meantime, CEG are supported by Protestant church communities in Austria and Germany. Biblical hermeneutics that follow historic realism have no less impact on social action than reading strategies that follow spiritual-abstract notions.

\section{Recommendations}

(1) The analysis shows the aberration of small but influential in-groups in Protestant church structures that promote antisemitism in church and society by enabling BDS. It is made obvious that there is a lack of external evaluation of church work performed by elected and tenured church servants. There also seems to be a lack of external legal options to stop immoral church behavior, such as antisemitism. The church system needs checks and balances. 
Suggestion: To establish a commission of (Jewish and Christian) strategists with the task to review Protestant ecclesiastical establishments for transparency.

(2) The investigation shows that there is a systemic public exclusion of theologies, theologians, and church leaders who see Israel favorably.

Suggestion: To establish Protestant church fora that promote Christian theologies and theologians which oppose antisemitism within the Protestant churches. Such fora would support the tasks of the Protestant churches.

(3) Replacement theology is an aggressive component in spreading antisemitism and BDS. It derives from the hermeneutics of the abstract spiritual ideal in the mind, the preferred reading strategy of liberal and post-modern intellectuals. Falsely labeled as being primitive and fundamentalist, hermeneutics of relative literalism and historic realism, precisely, enable the reduction and prevention of antisemitism.

Suggestion: To develop curricula that advance studies of hermeneutics with historic realism. Such curricula should endorse the traditional Mediterranean ethno-religious policy characterized by the fourfold unit of land, state, religion, and language.

(4) The study introduces the historic consciousness of Middle Eastern churches in view of Israel and the Muslim world.

Suggestion: Protestant churches establish studies with Israel and churches in Israel and in (former) Muslim countries, including Eastern and Southern Europe. Educational cooperation between West and East could become a key in fighting antisemitism in Protestant church settings.

Rev. Petra Heldt is head of the Ecumenical Theological Research Fraternity in Israel (ETRFI). Founded in 1966, the Fraternity studies and teaches Judaism and Christianity in Israel; developing mutual understanding between Jews and Christians, locally and internationally. Amongst several awards Heldt has received the Sir Sigmund Sternberg Award for Interfaith Understanding from the Hebrew University Jerusalem, a gold medal of the German Protestant Order of St. John and the Knesset Christian Allies Caucus Award to Honor Christian Allies.

\section{Bibliography}

Berrini Leblang, Deahn. "Area Jews Ask: Why Would a Church Show an anti-Semitic Movie?" Jewish Journal, November 2, 2017. https://jewishjournal.org/2017/11/02/area-jews-askwhy-would-a-church-show-an-anti-semitic-movie/. 
Brot für die Welt - Evangelischer Entwicklungsdienst. Kommt und seht! Reisen und Pilgern im Heiligen Land. Issued May 2016. https://shop.brot-fuer-die-welt.de/images/ 2016-06-28_pilgern_2016.pdf.

Chesler, Phyllis. "How I Was Rejected by Facebook-and Won.” Arutz Sheva, September 13, 2018. https://www.israelnationalnews.com/Articles/Article.aspx/22729.

Heldt, Petra. "Christen im Nahen Osten: Orientierungspunkt Israel." Kirche und Israel: Neukirchener Theologische Zeitschrift 32, no. 2 (2017): 153-65.

Heldt, Petra. "Fortpflanzung einer Mentalität." Kirche und Israel: Neukirchener Theologische Zeitschrift 33, no. 1 (2018): 5-15.

Heldt, Petra. "Mitri Raheb: Glaube unter imperialer Macht. Eine palästinensische Theologie der Hoffnung." Kirche und Israel: Neukirchener Theologische Zeitschrift 31, no. 2 (2016): $134-48$.

Heldt, Petra. "World Council of Churches Favors Nationalism and Anti-Semitism: The Kairos Palestine Document and Alternative Tourism." Gatestone Institute. Issued January 22, 2017. Accessed September 9, 2019. https://www.gatestoneinstitute.org/9800/wcc-kairosantisemitism.

International Holocaust Remembrance Alliance. "Working Definition of Antisemitism." Issued May 26, 2016. https://www.holocaustremembrance.com/news-archive/working-defi nition-antisemitism.

Lowe, Malcom. "Anti-israélisme, symptôme de crise des institutions." Le Christianisme au XXe Siecle 10 (1994): 60-62.

Lowe, Malcom. "World Council of Churches Struggles with the Truth-Again." Gatestone Institute. Issued March 6, 2016. Accessed September 9, 2019. https://www.gate stoneinstitute.org/7565/world-council-of-churches-water.

N. N. “Palestinian Christians Slam Pence's pro-Israel Faith.” Ynet News, January 22, 2018. https://www.ynetnews.com/articles/0,7340,L-5074816,00.html.

Ong, Czarina. "U.S. Vice President Mike Pence Reveals the Bible Verse that Hangs above his Mantle." Christian Today, February 4, 2017. https://www.christiantoday.com/article/vicepresident-mike-pence-reveals-the-bible-verse-thats-hangs-above-his-mantle/104411.htm.

van Dijk, Teun A. “Discourse and Manipulation.” Discourse \& Society 17, no. 3 (2006): $359-83$.

van Dijk, Teun A. “Discourse Studies and Hermeneutics.” Discourse Studies 13, no. 5 (2011): 609-21.

van Zile, Dexter. "CNN Errs in Relying On Anti-Israel Collaborator For Commentary About Israel." Camera, January 17, 2018. https://www.camera.org/article/cnn-errs-in-relying-onanti-israel-collaborator-for-commentary-about-israel/. 